Volume 6

Number 3 Survey on Oil \& Gas

Article 24

2020

\title{
The Fight for Footprint: Energy Development and Competing Surface Use Issues
}

James D. Bradbury

jim@bradburycounsel.com

Follow this and additional works at: https://scholarship.law.tamu.edu/journal-of-property-law

Part of the Oil, Gas, and Mineral Law Commons, and the Property Law and Real Estate Commons

\section{Recommended Citation}

James D. Bradbury, Courtney C. Smith \& Chandler Schmitz, The Fight for Footprint: Energy Development and Competing Surface Use Issues, 6. Tex. A\&M J. Prop. L. 256 (2020).

This Student Article is brought to you for free and open access by Texas A\&M Law Scholarship. It has been accepted for inclusion in Texas A\&M Journal of Property Law by an authorized editor of Texas A\&M Law Scholarship. For more information, please contact aretteen@law.tamu.edu. 


\title{
THE FIGHT FOR FOOTPRINT: ENERGY DEVELOPMENT AND COMPETING SURFACE USE ISSUES
}

\author{
James D. Bradbury, Courtney C. Smith \& Chandler Schmitz ${ }^{\dagger}$
}

\section{INTRODUCTION}

The laws surrounding energy development in Texas have evolved over the past century, ${ }^{1}$ as Texas has been at the epicenter of the energy industry - and thereby, the center of energy law-since oil was discovered in Corsicana in $1894 .^{2}$ Domestic, and even some international choice-of-law clauses, choose Texas law due to the Lone Star State's dominance in the energy sector. ${ }^{3}$

While Texas is often closely tied to oil and gas, its strong position in the energy market is not limited just to this industry. ${ }^{4}$ Texas is now the largest producer of wind energy and the seventh largest producer of solar energy in the United States. ${ }^{5}$ The plans to exponentially increase production of these alternative types of energy in the next five to ten years is reflected by the $\$ 2.5$ billion dollars that has been invested in wind and solar development in Texas. ${ }^{6}$

However, developing alternative energy sources creates an environment ripe for conflicts over land space as multiple parties seek to develop their respective forms of energy. ${ }^{7}$ While everything is bigger in Texas, things could start to feel significantly smaller if companies seek to produce several types of energy on the same, or close, area of land..$^{8}$

This Article discusses the advantages of Texas's continued growth in energy development - both traditional and alternative forms - and how to address the inevitable competition for land space

DOI: https://doi.org/10.37419/JPL.V6.I3.24

†Summer School Course, July 18-19, 2019 Galveston, Texas

1. Alan J. Alexander, The Texas Wind Estate: Wind as a Natural Resource and Severable Property Interest, 44 U. MICH. J.L. REFORM 429, 429-31 (2011).

2. $I d$.

3. $I d$.

4. Id.

5. Texas State Profile and Energy Estimates, U.S. ENERGY INFO. AND ADMIN. (Feb. 21, 2019), https://www.eia.gov/state/analysis.php?sid=TX\#121 [https://perma.cc/GZ6R-XKVF].

6. Id.

7. J. Brent Marshall, From Land or from Air: Why A Unified Energy Resource Scheme Is Necessary When the Answer Is Both, 8 BARRY U. ENVTL. \& EARTH L.J. 24, 25 (2018).

8. Id. at 26. 
that will occur when development of different natural resources is pursued in the same area. The author will also suggest ways that landowners can seek to protect their surface estate and preserve the current uses, such as agricultural operations, on their land.

\section{OIL AND GAS}

In Texas, similar to many other states, landowners can sever mineral and surface estates. ${ }^{9}$ Landowners can lease or sell the rights to one estate and retain the rights to the other. This is common when landowners lease mineral rights to oil and gas developers and retain rights to the surface estate in order to continue existing operations on the land.

Texas law is well-settled that the mineral estate is the dominant estate-meaning the surface estate is servient when it comes to developing minerals on the land. ${ }^{10}$ Issues arise when there is interest in developing more than one energy source on a given area of land, as Texas law is not clear on what "mineral" is dominant or if energy sources may be severable by type of source - oil and gas, wind, solar, and etc. ${ }^{11}$ A significant contributing factor to this conflict is that all the aforementioned energy sources require significant areas of surface space for development.

Accordingly, oil and gas developers that extract minerals from thousands of feet below the surface could be in direct competition with wind developers seeking to erect wind turbines. While this may seem counter-intuitive, the frustrating reality is that both operations require large areas of space, and often, more than one type of developer has a high interest in a particular area of land.

This leaves landowners and energy developers in a precarious situation of trying to determine how to proceed and which source has the dominant right to the land. ${ }^{12}$ At this time, the answer seems to be the mineral developer that first leased the land, and development rights

9. Tiffany Dowell, Texas Mineral Owner's Implied Right to Use the Surface, Tex. A\&M Agrilife Extension: Tex. Agric. L. BlOG (Nov. 26, 2018), https://agrilife.org/texasaglaw/2018/11/26/texas-mineral-owners-implied-right-touse-the-surface/ [https://perma.cc/4VMQ-9L8H].

10. Getty Oil Co. v. Jones, 470 S.W.2d 618, 621 (Tex. 1971); see also Merriman v. XTO Energy, Inc., 407 S.W.3d 244, 248-49 (Tex. 2013).

11. See Will RuSs, InHERITING THE WIND: A BRIEF GUIDE to RESOlving SPLiT Estate Issues When Developing Renewable Projects (2013), https://www.velaw.com/uploadedFiles/VEsite/Resources/SpecialInstituteRenewabl eElectricEnergyLawDevelopmentInvestment.pdf.

12. Marshall, supra note 7 , at 45. 
is likely the dominant estate and has the first right to develop. ${ }^{13}$ However, without further legal clarity, this current modus operandi could crumble.

This is largely due to the fact that, historically, when mineral and surface estates have been severed, oil and gas development has been considered the dominant estate. ${ }^{14}$ Accordingly, oil and gas developers would likely be able to block other wind and solar developments in favor of their own projects. ${ }^{15}$

Additionally, there is significant debate about whether wind and solar development should be considered mineral development or surface use. ${ }^{16}$ While wind and solar projects help develop valuable resources, the mineral estate has traditionally been understood to involve "capturing" minerals from below the surface. ${ }^{17}$ In response to this, wind and solar developers have begun implementing surface use agreements to strengthen their development rights. ${ }^{18}$

Surface use agreements are not novel in energy development in Texas. Landowners have long utilized these agreements to protect their surface use rights and to place certain restrictions on the reasonable access and area of land that oil and gas developers are authorized to utilize while operating on the land. ${ }^{19}$ Landowners could use these agreements when leasing to oil and gas developers to narrow the area of land these developers have access to, which may create opportunities for other types of energy development on the land. Alternatively, these agreements could be used in leases for alternative energy development to protect the relevant land space and narrow the scope of surface availability for oil and gas development.

If other types of energy sources are currently being developed on a certain area of land, oil and gas developers have a duty to not interfere with those operations. Texas common law has established the accommodation doctrine, which requires oil and gas developers to operate in a reasonable manner and to not interfere with the current surface use of the land. ${ }^{20}$

13. Id.

14. Id. at 37-38.

15. Id. at $47-48$

16. $I d$. at $41-42$.

17. Id. at $39-40$

18. Tara Righetti, Contracting for Sustainable Surface Management, 71 ARK. L. REV. 367, 384 (2018).

19. $I d$.

20. Id. at 371,377 . 
Surface owners can utilize this doctrine to challenge oil and gas operations on their land by showing the following: (1) existing surface use is being substantially impaired; (2) there is no reasonable alternative that would allow surface use operations to continue; and (3) the mineral owner has reasonable alternatives that would not impair surface use and would allow mineral development to continue. ${ }^{21}$ The accommodation doctrine could be used to protect existing alternative energy development on the land and as a method of forcing multiple developers to find ways to co-exist productively in a given space.

The Texas Railroad Commission has also established rules that restrict where oil and gas wells can be drilled. These rules regulate, among other things, the proximity of wells to each other, how close wells can be to property lines, and how many acres can constitute a drilling unit. ${ }^{22}$ While there can be exceptions to these rules when developers show good cause for a specific project, these regulations work to narrow the reasonable access developers have to land and also require developers to place wells in positions that do not overly burden the surface estate. ${ }^{23}$

The oil and gas industry is a vital and valued part of Texas and its economy, but there is a need to facilitate oil and gas development alongside other types of mineral development throughout the state. While certain existing legal doctrines and regulations assist in facilitating this, there is a need for either Texas courts or the Texas legislature to address the severability of different mineral estates from each other and to establish how the dominant mineral estate should be determined.

\section{WIND}

Wind has been a power source for over 5,000 years when people began sailing and used wind to propel a ship in the desired direction. Today, wind energy is the fastest-growing form of energy production in the United States. While wind energy is a renewable energy source and is generated from something with an essentially

21. Dowell, supra note 9.

22. Brandon E. Durrett, A Primer on Oil and Gas Regulations in Texas: Spacing, Density, Permits, Exceptions LANDMAN MAG. 35-37 (2013), https://www.dykema.com/media/site_files/120_NO_ADS_Durrett_Pub-NA.pdf.

23. . Id. at $40-41$. 
unlimited supply, this form of energy development is not without its thorns.

Wind energy production requires more physical land space than most oil and gas production projects because of the space needed to operate wind turbines - namely that the turbines should, ideally, be between 1,000-3,000 feet apart. Wind turbines also need a large amount of "buffer space" to prevent obstructions from blocking the flow of wind to the turbines. These buffer spaces are typically onehalf to one mile in distance and often require wind developers to acquire easements on neighboring properties so neighbors will not build structures that could create obstructions. The significant amount of surface space needed for wind production adds an additional layer of competition for land amongst energy developers in Texas.

Another thorn in the side of all parties involved in wind energy production is whether wind rights are severable from the surface estate, and who can - or should - be able to claim ownership of wind rights. Traditionally, property law theories would assign the right to wind flowing over a property to the owner of the surface estate. ${ }^{24}$ The rapid development of wind energy has presented state courts and legislatures across the country with the opportunity to determine if wind rights can be "severed" from the surface estate of the property. ${ }^{25}$

Several states have found wind rights to be a severable estate, and others have expressly prohibited severing wind rights. ${ }^{26}$ However, the majority of states, including Texas, have not made a formal determination about the severability of wind rights. ${ }^{27}$ Despite the fact that Texas has not formally determined whether wind is an independently severable estate, many Texas landowners are essentially severing wind rights from their surface estates via the wind development leases they are entering into with wind developers. ${ }^{28}$

24. Russ, supra note 11 , at 5.

25. Id.

26. Id.; see generally Troy A. Rule, Wind Rights Under Property Law: Answers Still Blowing in the Wind, 26 DEC. ProB. \& Prop. 56, 57 (2012); Alan J. Alexander, Note, The Texas Wind Estate: Wind as a Natural Resource and a Severable Property Interest, 44 U. MICH. J.L. REFORM 429, 444-51 (2011) (discussing analogous theories of the ownership of wind rights, including the law of wild animals, groundwater law, and surface water law).

27. See Alexander, supra note 26, at 433.

28. Id. ("Despite a lack of legislative and judicial guidance on this question, wind leases in Texas are typically written as if wind rights are severable. Yet it is unknown whether Texas courts will recognize the severability of a wind estate." ) 
Although, the validity of these severances remains to be seen in Texas jurisprudence. ${ }^{29}$

In response to the ambiguous state of wind rights in Texas, landowners and wind developers are currently using ground leases that grant the wind developer the right to use the surface estate to construct and operate the wind turbines. This development also limits the access the landowner, invitees, or other future potential energy developers may have to the area needed for the turbines. ${ }^{30}$ Surface use agreements are also used for wind development projects. These agreements still seek to protect the surface area needed for the wind project and also seek to delineate and protect the current or future rights of other direct and derivative estate owners on the land, such as oil and gas companies and pipeline companies. ${ }^{31}$

It is unclear how a conflict between the wind developer and the owners of other rights on a given property would be legally resolved. If the use pre-existed the wind development and is now impaired or prohibited by the wind development, other estate owners may be able to rely on the accommodation doctrine to preserve current uses of the land. ${ }^{32}$

However, the wind development industry in Texas - and all involved parties - will be relegated to operate in a nebulous space until the Texas legislature or the Texas courts determine whether the wind estate is severable from other rights on the land, and if so, whether this right should be considered part of the surface or mineral estate.

\section{SOLAR}

Solar energy is another form of alternative energy that is rapidly growing across the nation, and specifically, in Texas. A hurdle that is inhibiting solar energy development is determining who owns the rights to the sun and to which estate - surface or mineral - these rights belong. Texas courts have not determined that solar rights belong to the surface estate, but many legal scholars believe that Texas courts would find solar rights to belong to surface estate owners. ${ }^{33}$

This is legally significant because the solar development would likely be part of the surface estate and therefore would be a

29. Id.

30. Russ, supra note 11, at 13.

31. Id. at 14 .

32. Id. at 8 .

33. Dowell, supra note 9. 
servient estate to mineral development. ${ }^{34}$ This could create a significant quandary if the landowner has leased both mineral rights below the land and solar development on the surface estate because the mineral owner has the right to use all the land reasonably necessary for mineral production. Thus, solar developers must carefully analyze the status of the mineral estate on a surface area that they are interested in developing. ${ }^{35}$

Another hurdle is the staggering amount of land required to produce this type of energy. ${ }^{36}$ Solar production requires roughly 6,000 acres, and - unlike other types of energy development - this land is typically not usable for anything else. ${ }^{37}$ This is something landowners should be wary of when considering entering into a solar development lease. Most of these leases include prohibitions against using the land on which the panels are placed, as well as certain surrounding properties that may interfere with the sun's access to the panels. ${ }^{38}$ Further, many solar leases seek to prohibit certain agricultural operations, such as crop-dusting, which could be very detrimental to most rural landowners. ${ }^{39}$

While solar energy reduces a carbon footprint and utilizes a natural resource to produce clean energy, there are several unanswered legal and regulatory questions that create confusion and significant risks for those involved in solar production in Texas. The nebulous legal structure poses challenges to landowners and solar developers, and the nature of solar development is wholly adverse to other types of energy development because it renders the entire area of land unusable for any other purpose. For solar development to reach its potential, legal and regulatory advances must be made to determine ownership rights of solar rays and to which estate these rights belong.

\section{WATER}

The law surrounding groundwater ownership in Texas is far more settled, but that does not indicate that water development is without its challenges. Generally, groundwater is treated similar to oil and gas, and this legal theory was bolstered by the Texas Supreme

34. Id.

35. $I d$.

36. Ernest E. Smith et al., Everything Under the Sun: A Guide to Siting Solar in the Lone Star State, 12 TEX. J. OIL GAS \& ENERGY L. 41, 55 (2017).

37. J. Brent Marshall, supra note 7, at 31.

38. Dowell, supra note 9.

39. Id. 
Court's holding in Coyote Lake Ranch v. City of Lubbock. ${ }^{40}$ Here, the Court held that groundwater estates were severable from surface estates and therefore subject to the accommodation doctrine. ${ }^{41}$

The Court's reasoning in this case illustrated that Texas jurisprudence is committed to treating groundwater similar to oil and gas - in other words, as a mineral estate - and Texas courts are likely to find groundwater development to be a dominant estate. ${ }^{42}$ Texas courts also treat groundwater the same as oil and gas in that groundwater is subject to the rule of capture. ${ }^{43}$ However, the groundwater estate must be expressly severed for it to be a separate estate. Otherwise, the groundwater is considered part of the surface estate. $^{44}$

This treatment of groundwater presents a challenge when oil and gas development is in conflict with groundwater development, as it is unclear which of these "mineral" estates is dominant to the other. ${ }^{45}$ At this time, there is no case law to determine how a court would proceed if both the groundwater and mineral estates have been severed and are in development conflict with one another. ${ }^{46}$ To add a further wrinkle, there is no case law that determines how the accommodation doctrine would be utilized in the above scenario if there is also a conflict with surface use. ${ }^{47}$

Some legal scholars theorize that Texas's "first in time, first in right" theory would mean that the first estate to be severed would have the dominant rights. ${ }^{48}$ However, Texas has a strong public policy in favor of energy - oil and gas - development, and this may cause Texas courts to consistently find the oil and gas estate is dominant, which would force groundwater development and surface uses behind the reasonable needs to develop oil and gas. ${ }^{49}$

40. Coyote Lake Ranch LLC v. City of Lubbock, 498 S.W.3d 53, 65 (Tex. 2016).

41. Id. This holding provided clarity as to the priority of groundwater development over surface estate uses, but it also ensured that surface estate owners may utilize the accommodation doctrine to protect existing surface uses.

42. Haley King, Conflicts in Groundwater and Mineral Estates in Texas, 48 TEX. ENVTL. L. J. 299, 307 (2018).

43. Id. at 301 .

44. $I d$. at 299 .

45. Id. at 308 .

46. Id.

47. $I d$.

48. See Jared Berg, Ending the Game of Chicken: Proposed Solution to Keep Texas Wind Developers and Mineral Lesses from Ruffling Each Others' Feathers, 11 TEX. J. OIL AND GAS ENERGY L. 143, 156 (2016).

49. King, supra note 42, at 309. 
These sticky legal situations will likely-sooner rather than later-require the Texas legislature or the Texas courts to provide a legal framework that determines the developmental hierarchy between groundwater and mineral estates. Additionally, a determination is needed as to how the accommodation doctrine should apply when surface estate uses conflict with severed groundwater and mineral estates to reconcile these three important but competing uses of land.

\section{CONCLUSION}

Texas's booming energy market is the bedrock of Texas's strong economy and is a vital part of the state's continued growth and economic development. However, to ensure this growth continues, the Texas legislature or Texas courts must resolve competing uses for land space and development rights in Texas.

Both landowners and energy developers need a clear understanding of what rights are severable, how to contract to protect the viability of energy development projects, and how to protect landowners' important and existing surface uses. Further, developers need clarity as to which severable estates are dominant to one another and how conflicts will be resolved when two "dominant" estates come into developmental conflict with one another. 